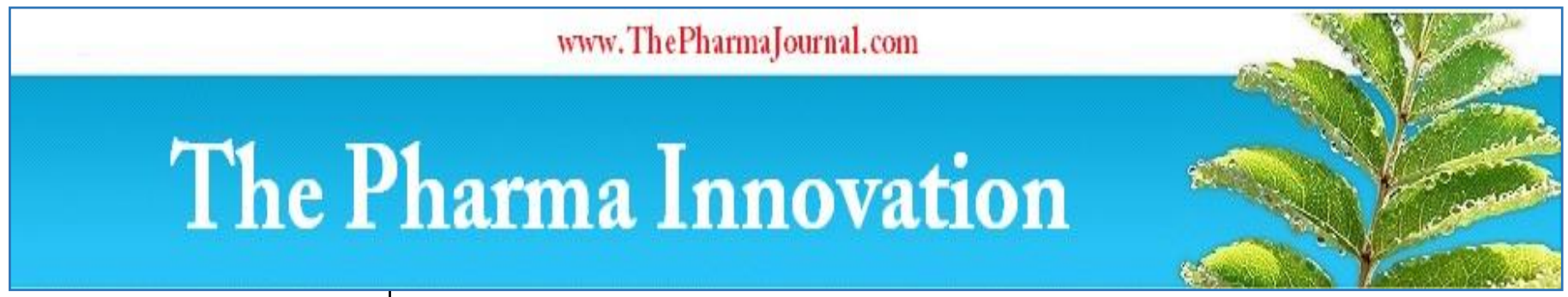

ISSN (E): $2277-7695$

ISSN (P): 2349-8242

NAAS Rating: $\mathbf{5 . 0 3}$

TPI 2020; 9(1): 404-407

(C) $2020 \mathrm{TPI}$

www.thepharmajournal.com

Received: 08-11-2019

Accepted: 12-12-2019

\section{Gaurav Yadav}

Warner College of Dairy

Technology, SHUATS

Prayagraj, India

John David

Professor, Warner College of Dairy Technology, SHUATS

Prayagraj -211007, India

\section{SN Thakur}

Assistant Professor, Warner College of Dairy Technology, SHUATS, Prayagraj, India

\section{Sangeeta Shukla}

Associate Professor, Warner College of Dairy Technology,

SHUATS, Prayagraj, India

\section{Anu Kumari}

Assistant. Professor, Warner College of Dairy Technology, SHUATS, Prayagraj, India

Vani Yadav

Student, Warner College of Dairy

Technology, SHUATS

Prayagraj, India

\section{Shalini}

Research Scholar, Warner College of Dairy Technology, SHUATS, Prayagraj, India

Corresponding Author:

Gaurav Yadav

Warner College of Dairy

Technology, SHUATS

Prayagraj, India

\title{
Evaluation of sensory attributes in different levels of Tapioca in pro-biotic Ice cream
}

\section{Gaurav Yadav, John David, SN Thakur, Sangeeta Shukla, Anu Kumari, Vani Yadav and Shalini}

DOI: https://doi.org/10.22271/tpi.2020.v9.i1g.4313

\begin{abstract}
The research was conducted to determine with the title "Effect of Different Levels of Tapioca (Manihot esculenta) as a Fat Replacer in low Fat Probiotic Ice Cream" to develop suitable technology for the preparation of fat replacer in low fat probiotic ice cream, to access the feasibility of using four levels $(5$, 10, 15 and 20\%) of tapioca (Manihot esculenta) with 1, 2 and 3\% of L. Casei. Total 12 treatment combination was used in this study as $\mathrm{T}_{1} \mathrm{~L}_{1}\left(5 \%\right.$ Tapioca $+1 \%$ L. Casei), $\mathrm{T}_{1} \mathrm{~L}_{2}(5 \%$ Tapioca $+2 \% L$. Casei $), \mathrm{T}_{1} \mathrm{~L}_{3}\left(5 \%\right.$ Tapioca $+3 \%$ L. Casei), $\mathrm{T}_{2} \mathrm{~L}_{1}\left(10 \%\right.$ Tapioca $+1 \%$ L. Casei), $\mathrm{T}_{2} \mathrm{~L}_{2}(10 \%$ Tapioca $+2 \%$ L. Casei $), \mathrm{T}_{2} \mathrm{~L}_{3}(10 \%$ Tapioca $+3 \%$ L. Casei $), \mathrm{T}_{3} \mathrm{~L}_{1}(15 \%$ Tapioca $+1 \%$ L. Casei $), \mathrm{T}_{3} \mathrm{~L}_{2}(15 \%$ Tapioca $+2 \%$ L. Casei), $\mathrm{T}_{3} \mathrm{~L}_{3}(15 \%$ Tapioca $+3 \%$ L. Casei $), \mathrm{T}_{4} \mathrm{~L}_{1}(20 \%$ Tapioca $+1 \%$ L. Casei $), \mathrm{T}_{4} \mathrm{~L}_{2}(20 \%$ Tapioca + $2 \%$ L. Casei $)$ and $\mathrm{T}_{4} \mathrm{~L}_{3}(20 \%$ Tapioca $+3 \% \mathrm{~L}$. Casei $)$ and all were replicated 4 times. The highest average value of colour and appearance score was obtained in the treatment $\mathrm{T}_{1} \mathrm{~L}_{3} 5 \%$ Tapioca $+3 \% \mathrm{~L}$. casei (8.72). The highest average value of body and texture score was obtained in the treatment $\mathrm{T}_{1} \mathrm{~L}_{3} 5 \%$ Tapioca $+3 \%$ L. casei (8.04). The highest average value of flavor and taste score was obtained in the treatment $\mathrm{T}_{1} \mathrm{~L}_{3} 5 \%$ Tapioca $+3 \% \mathrm{~L}$. casei (8.00). The highest average value of overall acceptability score content was obtained in the treatment $\mathrm{T}_{1} \mathrm{~L}_{3} 5 \%$ Tapioca $+3 \% \mathrm{~L}$. casei (8.12). the highest average value of melting score was obtained in the treatment $\mathrm{T}_{4} \mathrm{~L}_{3} 20 \%$ Tapioca $+3 \% \mathrm{~L}$. casei $(8.52)$. the highest average value of over run was obtained in the treatment $\mathrm{T}_{1} \mathrm{~L}_{1} 5 \%$ Tapioca $+1 \% \mathrm{~L}$. casei $(71.80)$.
\end{abstract}

Keywords: Tapioca, L. Casei, Body \& Texture, colour and appearance, flavor and taste, overall acceptability, melting score, over run in Low fat Ice-cream

\section{Introduction}

Icecream may be defined as a delicious sweet dessert which is obtained by suitable blending and processing of cream adding with some other flavoring ingredients or milk products with or without stabilizer color and with the incorporation of air during the freezing process. According to legal definition (PFA) ice cream is a frozen milk product which is obtained from cow or buffalo milk or combination or from cream and other milk product with or without addition of cane sugar, eggs, fruits, fruit juices, preserved fruits, nuts chocolate, edible flavors and permitted food colors. It may contain stabilizer and emulsifiers not exceeding $0.5 \%$ per cent by weight. It should contain not less than $10 \%$ fat, $3.5 \%$ protein and $36 \%$ total solids. This composition is exclusive of air. So, that they are based on the weight of Icecream mix. Ice cream is a whipped product or a cream which contain a great deal of air which effect the density of Icecream, prevent from being too hard and too cold in the mouth. Ice cream is a high calorie product with the calorie value is about $9.61 \sim 11 \mathrm{KJ} / \mathrm{g}(\mathrm{De}, 2006)^{[5]}$.

Ice cream industry in India has recent origin. It started in nineteen sixties. The icecream/frozen desserts category has witnessed substantial evolution. From the last 10 years, various traditional flavours has been developed in the category of Icecream, e.g.-Vanilla, Chocolate and strawberry along with some other variants like Kesarpista, Mewa Malai, Mango, Elaichi, Tradiotionalkulfi etc. The ice-cream market has been through an evolution wherein the category has grown in shape and form right from consumer perception to the products and services being offered. In India Amul leads first position in the market in the Icecream category covering almost one-third of the market, followed by Hindustan Uniliver and Mother Dairy. Baskin Robbins serves more than 25 flavors in their exclusive stores. Vadilal has also the wide range of Icecream in the country serves 150 plus flavors, sold in a variety of more than 300 packs and forms. Ice cream has an evolving market growing at a CAGR of over $4 \%$. Recent surveys results shows that there is broad jump in ice cream consumption is in the low-fat and non-fat ice creams categories. 
As compare to other surveys results showed that low-fat icecream gaining more popularity than the non-fat Icecream. (Anonymous, 2018) ${ }^{[1]}$. This market trend Isseen in most developed countries because of consumer concern about the impact of dieton health.

Probiotic foods are those foods which contain live bacteria and yeast which is good for human health and it is used in food in an adequate matrix with sufficient concentration, so that after their ingestion, the postulated effect is obtained, and is beyond that of usual nutrient suppliers. (Saxelin and De Vos., 2005) ${ }^{[22]}$.

Dairy products have been considered as a good carrier for probiotics since fermented foods and dairy products have particularly a positive image. A major advantage is that consumers are already familiar with them and many believe that dairy products are healthy, natural products. Dairy ingredients also allows the production of diverse textures and aromas, adding another benefit with the possible range of sensory characteristics. Probiotics help to maintain good balance and composition of intestinal flora increasing the ability to resist pathogens invasion and maintain the host's wellbeing. It also helps in reduction of blood pressure, cholesterol and/or triglycerides levels, reduction of lactose intolerance problems, immune system enhancement, anticarcinogenic activity and improve nutrients utilization. The use of probiotics for preventing and treating illnesses related to gastrointestinal, respiratory and urogenital tracts have been studied. They have been widely used in therapeutic applications as constipation, diarrhea control, bowel syndrome, control of inflammatory processes, prevention of eczema, osteoporosis and food allergy (Aureli et al., 2011; Ranadheera et al., 2010; Rastall et al., 2000; Vasiljevic and Shah, 2008) ${ }^{[7,8,9,10]}$. The most common probiotic strains used in dairy foods belong to Lactobacillus (L.acidophilus, $L$. johnsonii, L. gasseri, L. crispatus, L. Casei/paracasei, L. rhamnosus, L. reuteri, L.plantarum) and Bifidobacterium (Bifidobacteriumlactis, B. bifidum, B. infantis, B. breve, $B$. animalis, B. adolescentis) genera.

Tapioca (Manihotesculenta), also called manioc, cassava or yuca, it is one of the most important food crops which is being particularly suited to serve as a meal with sufficient nutrition value and able to survive drought or other natural disasters. (Burrell, 2003) [11]. Among the starchy staples, cassava is a rich source of carbohydrate production which contain about $40 \%$ higher than rice and $25 \%$ more than maize, so all these parameters gives the result that cassava is the cheapest source of calories for both human nutrition and animal feeding. A typical composition of the cassava root is moisture $(70 \%)$, starch $(24 \%)$, fiber $(2 \%)$, protein $(1 \%)$ and other substances including minerals $(3 \%)$.Tapioca powder contain $13.2 \%$ moisture, $0.6 \%$ Protein, $85 \%$ carbohydrate and $0.2 \%$ fat. Cassava starch can be converted to maltotriose, maltose, and glucose as well as to other modified sugars and organic acids (Tan et al. 1984) ${ }^{[13]}$. Starch from cassava can be used to make fructose syrups (Vuilleumier, 1993) ${ }^{[14]}$ and formulate gelatin capsules (Nduele et al. 1993) ${ }^{[15]}$. The use of cassava as a source of ethanol for fuel is already being exploited and very promising. There are several health benefits of tapioca. It help in healthy weight gain, increase circulation and red blood cell count, protect against birth defects, improve digestion, lower cholesterol, prevent diabetes, improve metabolic activities, protect bone mineral density, protect from Alzheimer's disease, maintain heart health, and fluid balance within the body.

With the changing health scenario the demand for calorie reduced foods by consumers is now greater than ever because most adults are overweight. Dietary fat recommendations have motivated declines in consumption of many high fat content foods, including dairy products, because the amount of fat in the diet, having a high correlation with various illnesses, such as obesity and heart disease, which is the top concern for consumers (Sarker and Rahman, 2017) ${ }^{[20]}$. As a consequence, the dairy industry has developed a variety of low-fat or fat-free ice cream products in order to cater to this tendency. In the modern era, consumer's choice depends not only on the nutritional image of a food product but also sensory qualities of appearance, texture and flavor (Shamil and Kilcast, 1992) ${ }^{[16]}$.

Keeping in mind the changing health scenario, public awareness and health benefits of probiotics and tapioca, the objectives of this study was:

1. To prepare probiotic ice cream with different ratio of tapioca.

2. To study sensory parameter of probiotic ice cream.

\section{Materials and methods}

The experiments were carried out in the Research Laboratory, Warner College of Dairy Technology, SHUATS, Prayagraj (U.P.).Raw milk was procured from Experiential Dairy Plant "Aggies" of SHUATS, Prayagraj. Sugar was procured from local market of Prayagraj. Tapioca powder (Flavourlite, ozale e-commerce Pvt. Ltd., Kollam, India) was procured from Delhi. Stabilizer, emulsifier and flavor (Vanilla) was procured from experiential dairy plant "Aggies" of SHUATS, Prayagraj. Probiotic culture was procured from NDRI, Karnal. The different treatment combination of this study have been listed in Table 1. Total number of treatment combination in this study was 12. Probiotic ice-cream with different level of Tapioca powder was prepared as per flow diagram shown in Fig. 1.

Table 1: Treatment combinations of different level of Tapioca powder and probiotic culture

\begin{tabular}{|c|c|c|c|}
\hline S. No. & Treatment Code & Tapioca powder\% & Culture (L. Casei.) \% \\
\hline 1. & $\mathrm{~T}_{1} \mathrm{~L}_{1}$ & 5 & 1 \\
\hline 2. & $\mathrm{~T}_{1} \mathrm{~L}_{2}$ & 5 & 2 \\
\hline 3. & $\mathrm{~T}_{1} \mathrm{~L}_{3}$ & 5 & 3 \\
\hline 4. & $\mathrm{~T}_{2} \mathrm{~L}_{1}$ & 10 & 1 \\
\hline 5. & $\mathrm{~T}_{2} \mathrm{~L}_{2}$ & 10 & 2 \\
\hline 6. & $\mathrm{~T}_{2} \mathrm{~L}_{3}$ & 10 & 3 \\
\hline 7. & $\mathrm{~T}_{3} \mathrm{~L}_{1}$ & 15 & 1 \\
\hline 8. & $\mathrm{~T}_{3} \mathrm{~L}_{2}$ & 15 & 2 \\
\hline 9. & $\mathrm{~T}_{3} \mathrm{~L}_{3}$ & 15 & 3 \\
\hline 10. & $\mathrm{~T}_{4} \mathrm{~L}_{1}$ & 20 & 1 \\
\hline 11. & $\mathrm{~T}_{4} \mathrm{~L}_{2}$ & 20 & 2 \\
\hline 12. & $\mathrm{~T}_{4} \mathrm{~L}_{3}$ & 20 & 3 \\
\hline
\end{tabular}




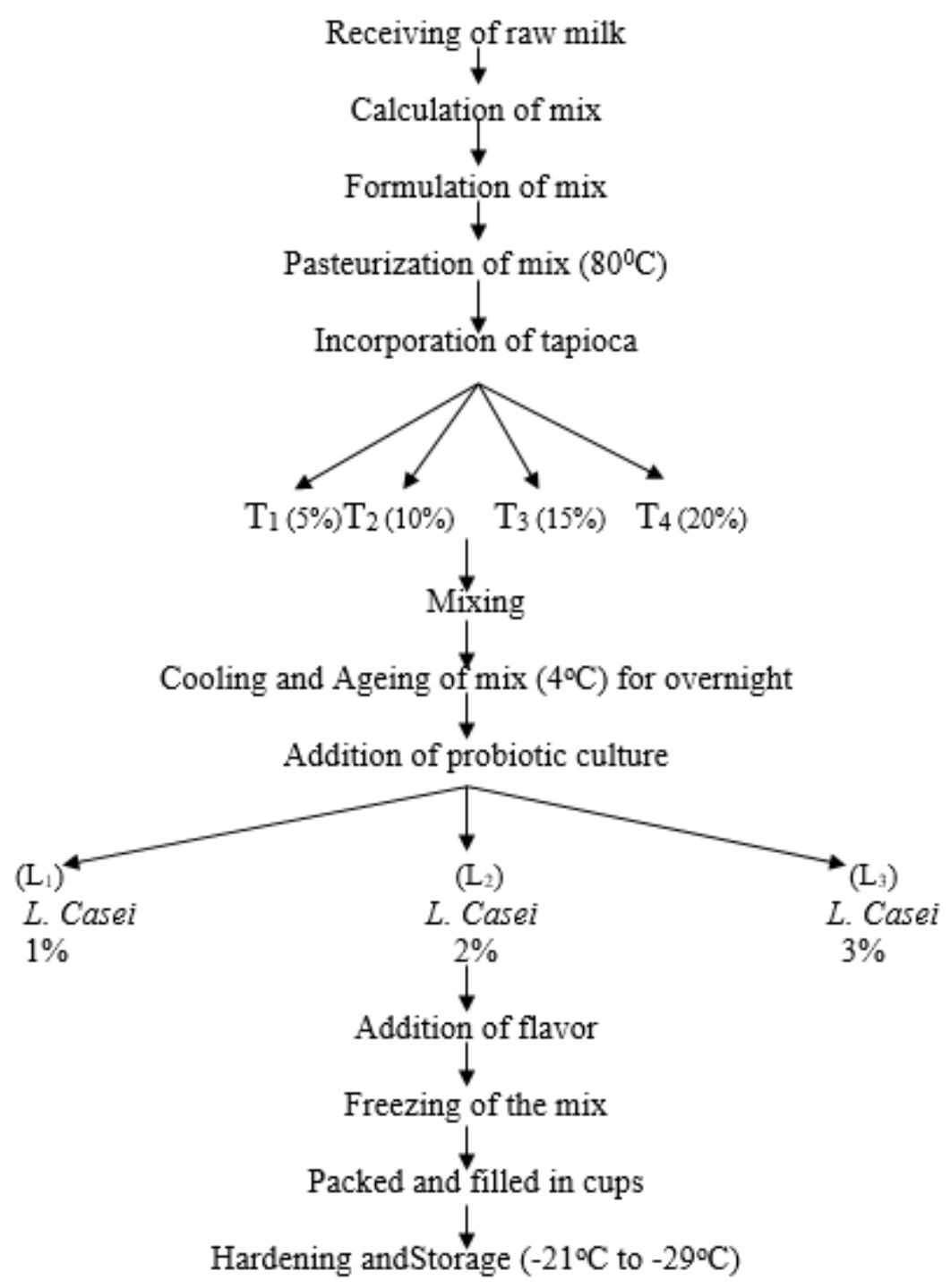

Fig 1: Flow diagram for preparation of low fat probiotic ice-cream with different ratio of tapioca powder

Statistical analysis: The data obtained were statistically analyzed by Analysis of Variance (ANOVA) at 5\% level of significance using SPSS version 16 software.

\section{Results and Discussion}

Different samples of probiotic ice-cream in each replication were evaluated for Colour \& Appearance, Body \& Texture, Flavor \& Taste, Overall acceptability, Melting Point, Over run. The data of Sensory parameters and cost of production of this study were tabulated in Table 2, respectively.

Colour and appearance: The Colour \& Appearance of probiotic ice-cream in different level of tapioca shown in Table 2. Colour \& Appearance of all the treatment was significantly decreased $(P<0.05)$ as the level of tapioca increased. Colour \& Appearance content of product was higher with $5 \%$ of tapioca starch and lower with $20 \%$ tapioca starch with Colour \& Appearance of $8.72-7.16 \%$ respectively.

Body and texture: Body \& Texture percentage in tapioca probiotic ice-cream of all the treatment was significantly decreased $(P<0.05)$ as the level of tapioca increased. Body \& Texture content of product was higher with $5 \%$ of tapioca starch and lower with $20 \%$ tapioca starch with Body \& Texture of $8.04-7.24\left(\mathrm{~T}^{4} \mathrm{~L}^{1} \& \mathrm{~T}^{4} \mathrm{~L}^{2}\right) \%$ respectively.
Flavor and taste: Flavor \& Taste content of developed product was decreased significantly $(\mathrm{p}>0.05)$ with addition of tapioca powder shown in Table 2. all the treatment was significantly decreased $(P<0.05)$ as the level of tapioca increased. Flavor \& Taste content of product was higher with $5 \%$ of tapioca starch and lower with $20 \%$ tapioca starch with Flavor \& Taste of $8.00-6.64\left(\mathrm{~T}^{4} \mathrm{~L}^{3}\right) \%$ respectively.

Overall acceptability: Overall acceptability of developed probiotic ice-cream was found $\mathrm{T}^{1} \mathrm{~L}^{3}$ (8.12) has the maximum value and the minimum value is $6.84\left(\mathrm{~T}^{4} \mathrm{~L}^{3}\right)$ which was significantly different $(P<0.05)$ in all the treatment. Results also revealed that as the percentage of tapioca decreased Overall acceptability in sample. Increase in Overall acceptability content in sample may be due to imparting of present in tapioca.

Melting Score: Melting score percent in probiotic ice-cream was found $\left(\mathrm{T}^{4} \mathrm{~L}^{3}\right) 8.52$ was maximum $\%$ and minimum was $\left(\mathrm{T}^{1} \mathrm{~L}^{3}\right) 7.46$ which was significantly different $(P<0.05)$ in all the treatment. Data regarding Melting Score content in all the sample (Table 2) showed that Melting Score of ice-cream increased as the tapioca percent increased.

Over run: Over run score percent in probiotic ice-cream was found $\left(\mathrm{T}^{1} \mathrm{~L}^{1}\right) 71.80$ was maximum $\%$ and minimum was 
$\left(\mathrm{T}^{4} \mathrm{~L}^{3}\right) 64.60$ which was significantly different $(P<0.05)$ in all the treatment. Data regarding over run content in all the sample (Table 2) showed that over run of ice-cream decreased as the tapioca percent increased.

Table 2: Average of all chemical data obtained in different treatment combination of probiotic tapioca ice-cream

\begin{tabular}{|c|c|c|c|c|c|c|}
\hline Treatments & $\begin{array}{c}\text { Colour \& Appearance } \\
(\%)\end{array}$ & $\begin{array}{c}\text { Body \& Texture } \\
(\%)\end{array}$ & $\begin{array}{c}\text { Flavor \& Taste } \\
(\%)\end{array}$ & $\begin{array}{c}\text { Overall acceptability } \\
(\%)\end{array}$ & $\begin{array}{c}\text { Melting Score } \\
(\%)\end{array}$ & $\begin{array}{c}\text { Over run } \\
(\%)\end{array}$ \\
\hline $\mathrm{T}_{1} \mathrm{~L}_{1}$ & 8.00 & 8.00 & 7.44 & 7.76 & 7.76 & 71.80 \\
\hline $\mathrm{T}_{1} \mathrm{~L}_{2}$ & 7.92 & 7.68 & 7.88 & 7.77 & 7.68 & 70.80 \\
\hline $\mathrm{T}_{1} \mathrm{~L}_{3}$ & 8.72 & 8.04 & 8.00 & 8.12 & 7.46 & 71.00 \\
\hline $\mathrm{T}_{2} \mathrm{~L}_{1}$ & 8.20 & 7.76 & 7.68 & 7.75 & 8.12 & 69.20 \\
\hline $\mathrm{T}_{2} \mathrm{~L}_{2}$ & 8.00 & 7.80 & 7.52 & 7.72 & 8.26 & 69.20 \\
\hline $\mathrm{T}_{2} \mathrm{~L}_{3}$ & 7.36 & 7.64 & 7.44 & 7.43 & 8.18 & 67.80 \\
\hline $\mathrm{T}_{3} \mathrm{~L}_{1}$ & 7.48 & 7.40 & 7.48 & 7.33 & 8.18 & 67.60 \\
\hline $\mathrm{T}_{3} \mathrm{~L}_{2}$ & 7.36 & 7.72 & 7.24 & 7.30 & 8.40 & 66.40 \\
\hline $\mathrm{T}_{3} \mathrm{~L}_{3}$ & 7.52 & 7.32 & 7.32 & 7.28 & 8.44 & 65.40 \\
\hline $\mathrm{T}_{4} \mathrm{~L}_{1}$ & 7.48 & 7.24 & 7.12 & 7.20 & 8.50 & 65.80 \\
\hline $\mathrm{T}_{4} \mathrm{~L}_{2}$ & 7.40 & 7.24 & 7.08 & 7.01 & 8.46 & 65.00 \\
\hline $\mathrm{T}_{4} \mathrm{~L}_{3}$ & 7.16 & 7.28 & 6.64 & 6.84 & 8.52 & 64.60 \\
\hline
\end{tabular}

\section{Conclusion}

It can be concluding that the low fat probiotic ice cream made by Tapioca was tested by comparing it with the standard of ice cream, it was observed from results that better quality ice cream can be prepared by using Tapioca, Skim milk powder, Milk and Sugar. Tapioca having good source of vitamin $\mathrm{C}$ and Calcium and Phosphorus and probiotics can improve the digestion and boost the immune system in humans. It was observed from results that the prepared ice cream found to be having low fat \% when compared with the standard and acceptance of product was marvelous as per the sensory panel. Among all 12 treatment of probiotic low fat ice cream containing tapioca in the 4 ratio of $\left(\mathrm{T}_{1} \mathrm{~L}_{1}, \mathrm{~T}_{1} \mathrm{~L}_{2}, \mathrm{~T}_{1} \mathrm{~L}_{3}\right) 5 \%$, $\left(\mathrm{T}_{2} \mathrm{~L}_{1}, \mathrm{~T}_{2} \mathrm{~L}_{2}, \mathrm{~T}_{2} \mathrm{~L}_{3}\right) \quad 10 \%, \quad\left(\mathrm{~T}_{3} \mathrm{~L}_{1}, \mathrm{~T}_{3} \mathrm{~L}_{2}, \mathrm{~T}_{3} \mathrm{~L}_{3}\right) \quad 15 \%, \quad\left(\mathrm{~T}_{4} \mathrm{~L}_{1}\right.$, $\left.\mathrm{T}_{4} \mathrm{~L}_{2}, \mathrm{~T}_{4} \mathrm{~L}_{3}\right) 20 \%$ with probiotic culture ratio of $1 \%\left(\mathrm{~T}_{1} \mathrm{~L}_{1}\right.$, $\left.\mathrm{T}_{2} \mathrm{~L}_{1}, \mathrm{~T}_{3} \mathrm{~L}_{1}, \mathrm{~T}_{4} \mathrm{~L}_{1}\right), 2 \%\left(\mathrm{~T}_{1} \mathrm{~L}_{2}, \mathrm{~T}_{2} \mathrm{~L}_{2}, \mathrm{~T}_{3} \mathrm{~L}_{2}, \mathrm{~T}_{4} \mathrm{~L}_{2}\right), 3 \%\left(\mathrm{~T}_{1} \mathrm{~L}_{3}\right.$, $\left.\mathrm{T}_{2} \mathrm{~L}_{3}, \mathrm{~T}_{3} \mathrm{~L}_{3}, \mathrm{~T}_{4} \mathrm{~L}_{3}\right)$.

\section{References}

1. Anonymous. The state of the global ice cream market. Kerry digest blog, published: Alexis Hosch. Retrived from $13^{\text {th }}$ August, 2018.

2. AOAC. Official Methods of Analysis. $15^{\text {th }}$ Edition, Association of Official Analytical Chemist, Washington DC, 1990.

3. AOAC. Association of Analytical Chemist) Standard Official Methods of Analysis of the Association of Anlytical Chemists. $14^{\text {th }}$ Edition, SW. Williams, Washington DC, 1984, 121p.

4. American Public Health Association (APHA). Standard Methods for Examination of water, 1992.

5. De S. Outlines of dairy technology. Publisher: Oxford University Press, New Delhi, India, 2006.

6. Tynkkynen M, Mattila-Sandholm TS, De Vos WM. Probiotic and other functional microbes: from markets to mechanism. Current opinion in biotechnology. 2005; 16(2):204-211.

7. Aureli P, Capurso L, Castellazzi AM, Clerici M, Giovannini M, Morelli L et al. Probiotics and health: an evidence based review. Pharmacology Research, 2011; 63(5):366-376.

8. Ranadheera RDCS, Baines SK, Adams MC. Importance of food in probiotic efficacy. Food Research International. 2010; 43:1-7.

9. Rastall RA, Fuller R, Gaskins HR. Colonic functional foods. In: Dairy Processing, Gibson G.R., Williams C.M. (eds.), CRC Press, Boca Raton, 2000, 71-89.

10. Vasiljevic T, Shah NP. Probiotics -From Metchnikoff to bioactives. International Dairy Journal. 2008; 18:714728.

11. Burrell MM. Starch: the need for improved quality or quantity--an overview. Journal of Experimental Botany. 2003; 54(382):451-456.

12. Emir. J Food Agric. 2016; 28(8).

13. Tan KH, Ferguson LB, Carlton C. Conversion of cassava starch to biomass, carbohydrates, and acids by Aspergillusniger. Journal of Applied Biochemistry, 1984; 6(1-2):80-90.

14. Vuilleumier S. Worldwide production of high-fructose syrup and crystalline fructose. American Journal of Clinical Nutrition. 1993; 58(5):733S-736S.

15. Nduele M, Ludwig A, van ooteghem $M$. The use of cassava starch in the formulation of gelatin capsules. Journal de Pharmacie de Belgique, 1993; 48(5):325-334.

16. Syed Shamil Lisa, Wyeth David Kilcast J. Flavour release and perception in reduced-fat foods Food Quality and Preferenc. 1991-1992; 3(1):51-60.

17. Ranganna S. Handbook of analysis and quality control for fruit and vegetable products. 2nd edn, Tata McGrawHill Publ, New Delhi, 1986.

18. Ranganna S. Handbook of Analysis of Quality Control for Fruit and Vegetable Products, Tata McGraw-Hill Publ. Co., New Delhi, India, 1995.

19. Bakshi MPS, Wadhwa M. Nutritional evaluation of baby corn husk - A new feed resource for livestock. Indian J. Anim. Sci. 2012; 82(12):1548-1550.

20. Sarker M, Rahman M. Dietary fiber and obesity Management. Journal-Advances in Obesity Management. 2017; 7:3.

21. Cruz-Requena M, Aguilar-Gonalez CN, Prado-Barragan LA, Cunha MDG, Correia MTDS. Contreras-Esquivel J.C., Rodriguez-Herrera Raul., Dietryfiber: An ingredient against obesity. Emirates Journal of Food and Agriculture. 2016; 28(8):522-530.

22. Saxelin M, De Vos WM. Probiotic and other functional mocrobes: from markets to mechanisms. Current Opinion in Biotechnology. 2005; 16(2):204-211. 